\title{
Advanced packaging for distribution and storage of COVID-19 vaccines: a review
}

\author{
Dakuri Ramakanth $^{1} \cdot$ Suman Singh ${ }^{2} \cdot$ Pradip K. Maji $^{1} \cdot$ Youn Suk Lee $^{3} \cdot$ Kirtiraj K. Gaikwad $^{4} \oplus$
}

Received: 28 April 2021 / Accepted: 19 May 2021 / Published online: 3 June 2021

(c) The Author(s), under exclusive licence to Springer Nature Switzerland AG 2021

\begin{abstract}
The outbreak of the coronavirus disease 2019 global pandemic (COVID-19) has affected billions of lives, posing critical challenges to the healthcare system, vaccine manufacturers, packaging scientists, and daily public activity. Biotechnological advances have allowed to create rapidly vaccines, yet the success of an efficient immunization mainly depends on the safe and timely delivery of vaccines. In particular, packaging plays a crucial role in protecting, preserving, transporting, and distributing vaccines. Here, we review advanced packaging for distribution and storage of COVID-19 vaccines, with focus on innovative hybrid packaging materials, cyclic olefin polymers with nanolayer glass, and vials for vaccines. We present vaccine packaging, auto-disable syringes, stoppers, and closures. We discuss the chronology of the packaging system, and the labeling of the vaccine packages, with emphasis on bar codes, quick response codes, vaccine vial monitors, anticounterfeiting and traceability measures.
\end{abstract}

Keywords COVID-19 $\cdot$ SARS-CoV-2 $\cdot$ COVAX $\cdot$ Vaccine $\cdot$ Packaging $\cdot$ Coronavirus $\cdot$ Pandemic

$\begin{array}{ll}\text { Abbreviations } & \\ \text { 2D } & \text { Two dimensional } \\ \text { CFR } & \text { Code of Federal Regulations } \\ \text { COVAX } & \text { COVID-19 Vaccines Global Access } \\ \text { COVID-19 } & \text { Corona virus disease of 2019 } \\ \text { EEC } & \text { European Economic Community } \\ \text { GTIN } & \text { Global Trading Identification Number } \\ \text { IDC } & \text { International Data Corporation } \\ \text { IMPACT } & \text { International Medical Products Anti- } \\ & \text { Counterfeiting Taskforce }\end{array}$

Youn Suk Lee

leeyouns@yonsei.ac.kr

$\triangle$ Kirtiraj K. Gaikwad

kirtiraj.gaikwad@pt.iitr.ac.in

1 Department of Polymer and Process Engineering, Indian Institute of Technology Roorkee, Roorkee, Uttarakhand 247667, India

2 Department of Food Engineering, Institute of Food Science \& Technology, VCSG Uttarakhand University of Horticulture and Forestry, Majri grant, Dehradun, Uttarakhand 248140, India

3 Department of Packaging, Yonsei University, Wonju, Gangwon-do 220-710, South Korea

4 Department of Paper Technology, Indian Institute of Technology Roorkee, Roorkee, Uttarakhand 247667, India
ISO International Organization for

Standardization

PIL Patient Information Leaflet

SARS-CoV-2 Severe Acute Respiratory Syndrome CoronaVirus-2

TRS Technical report series

ULT Ultra-low temperature

UNICEF United Nations International Children

Emergency Fund

USFDA United States Food and Drug

Administration

VPPAG Vaccine Presentation and Packaging

Advisory Group

VVM Vaccine Vial Monitors

WHO World Health Organization

\section{Introduction}

The outbreak of novel coronavirus disease 2019 global pandemic (COVID-19) has affected billions of lives, posing critical challenges to the health care system, vaccine manufacturers, packaging scientists, and daily public activity (Chen et al. 2021; Choi et al. 2021a; Fauci et al. 2020). The virus, popularly known as severe acute respiratory syndrome coronavirus-2 (SARS-CoV-2), has been affecting the whole 
world for more than a year (Choi et al. 2021b; Han et al. 2021). The name SARS-CoV-2 was provided by the International Committee on Taxonomy of Viruses (Wang et al. 2020). The disease was named COVID-19 by the World Health Organization (WHO) in consultation with the World Organization for Animal Health and United Nations Food and Agriculture Organization (WHO 2021a). According to the WHO, there are 131.5 million cases in total and approximately 2.8 million deaths reported on April 5, 2021, due to the deadly virus. This fatal disease has put the global community on the verge of collapse (Sharma et al. 2021; Sharma et al. 2021). However, due to the continual efforts from vaccine manufacturers, research and development centers, and other scientific fraternity, there has been a timely development of vaccines and effective supply chains for delivering the same (He et al. 2021; WHO 2020a).

Packaging and shipping allow the modern world to function at ever-increasing levels of complexity (Gaikwad et al. 2018; Singh et al. 2018). Allowing your products to be effectively and efficiently packaged and shipped to you saves you the hassle of having to do it yourself (Gaikwad et al. 2019). A previous study (Haynes et al. 2020) mentions, "There will be no COVID-19 vaccine without right packaging." A vaccine can be made, however, without proper packaging and storage throughout the entire supply chain, vaccination will be ineffective. There was ambiguity at the beginning of the vaccine production about its storage, material, and temperature at which it can be transported. The emergence of cutting-edge technologies and state-of-the-art facilities in India and across the globe has facilitated the vaccine-making processes. Approximately, 200 vaccine candidates are currently being developed, and a few of them require ultra-low temperatures (ULT) and a controlled temperature chain, whereas some others require a standard cold supply chain (WHO 2021b). Figure 1 Illustrates typical packaging and distribution system for the COVID-19 vaccine consists of different packaging levels maintaining cold storage throughout the supply chain for a successful vaccination program.

The United States Food and Drug Administration has issued guidelines for vaccine manufacturers regarding storage and temperature monitoring. The end consumer should be aware of the history of the product storage conditions. The use of digital temperature sensors such as thermocouples, resistance temperature detectors, or thermistors can provide accurate data, and purpose-built units or pharmaceutical grade units can be used instead of household or dormitorystyle refrigerators or freezers (Shastri 2013). Waste handling post-vaccination is the biggest challenge (Sun et al., 2021). As the vaccine campaign has already started, and billions of doses are being administered, there are concerns over the disposal of primary packaging (vials and syringes), secondary packaging (cartons), tertiary packaging (corrugating

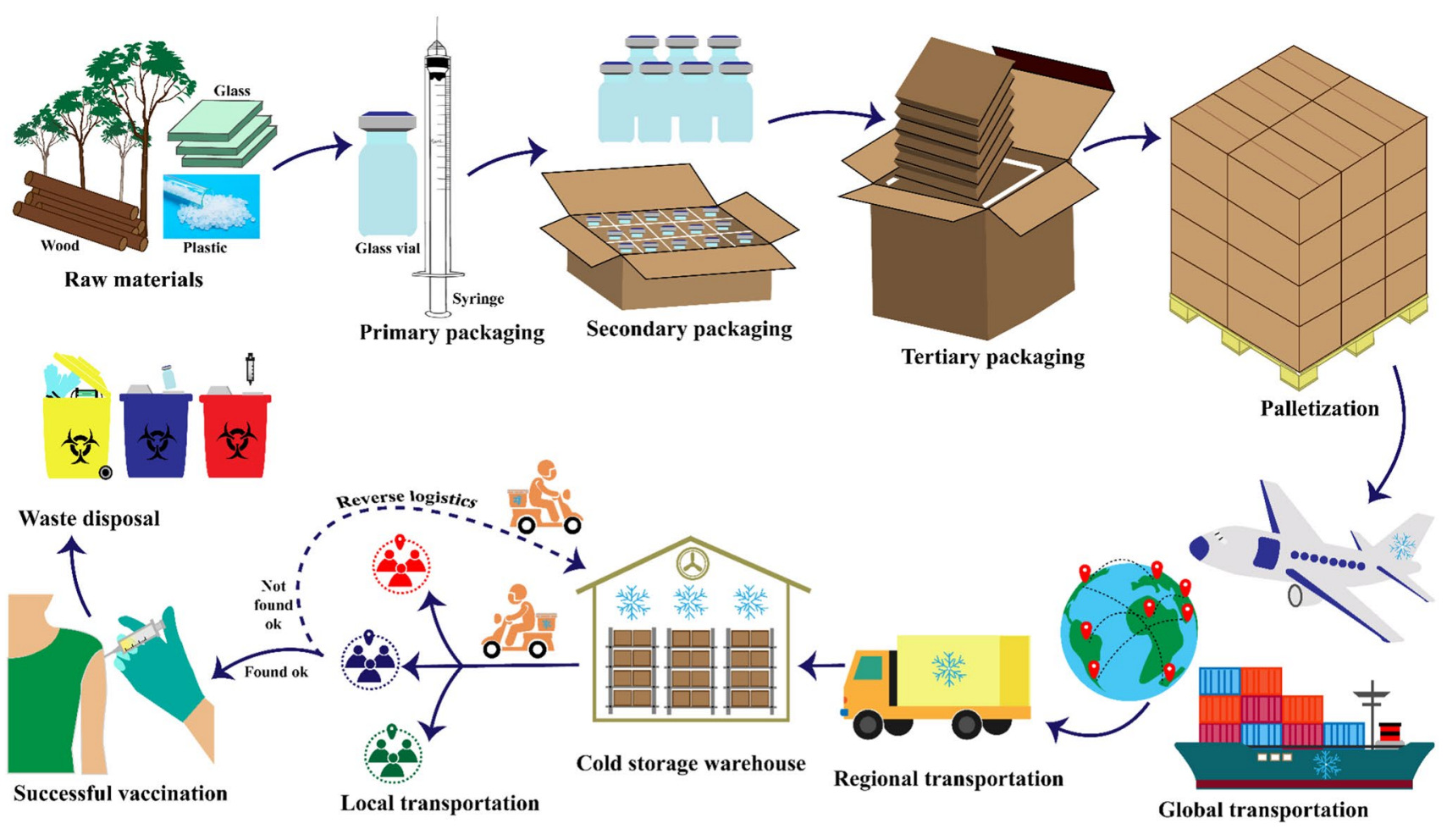

Fig. 1 Packaging and distribution of the coronavirus disease vaccine consisting of different packaging levels that maintain cold storage throughout the supply chain for a successful vaccination program 
boards), and cushioning material and injectable items. In addition to the vaccine packaging material, the disposal of personal protective equipment kits is also of prime concern. A proper set of guidelines for waste disposal has not been established yet (NDTV 2021).

In this comprehensive review, we summarize the role of advance packaging system for the distribution and storage of COVID-19 vaccines without deterioration. To the best of our knowledge, there are no review papers on the COVID-19 vaccine packaging system. First, we discuss primary packaging materials, such as glass vials and syringes, along with stoppers and seals. We then discuss packaging for distribution, which includes secondary and tertiary packaging for vaccines. Later, we provide an overview of different labeling types used for primary, secondary, and tertiary packaging, barcodes, and packaging inserts.

\section{Primary packaging system for COVID-19 vaccines}

\section{Glass vials}

Borosilicate glass vials are the most used material for packaging vaccines because of their inertness. More than 50 billion glass vials are produced and sold globally for various purposes. Glass vials are commonly used in a wide variety of vaccines and treatments (Sumant 2021). SCHOTT, a global conglomerate, is one of the largest manufacturers of pharmaceutical packaging units with 20 approved glass and converting plants globally. Three out of four vaccine projects undergoing clinical trials used SCHOTT vials for their vaccine campaigns. In total, it produces approximately 11 billion glass vials per annum, and the estimated target supply for the COVID-19 vaccine campaign is approximately 2 billion doses by the end of 2021 (SCHOTT 2021). The global pharmaceutical glass vial manufacturers' community includes major market players such as SCHOTT, Corning, Stevanto group, Gerresheimer, and DWK Life Sciences, which have increased their capacity and quality due to the ongoing demand. Although there is a need for improved packaging over simple glass vials due to different storage conditions required for COVID-19 vaccines, and considering the ongoing pandemic, some vaccine manufacturers are likely to adopt the existing packaging format. However, other vaccine manufacturers such as Pfizer-BioNTech and ModernaTx, where ultra-low temperatures are required, need to opt for different materials (WHO 2021b; IMD 2020). A typical glass vial, along with the closures, is shown in Fig. 2 .

The need to shift the focus to develop new materials for vials might be due to leaching of glass material to the drug, to reduce breakage during manufacturing, faster time to market, to decrease load during transportation, thus reducing

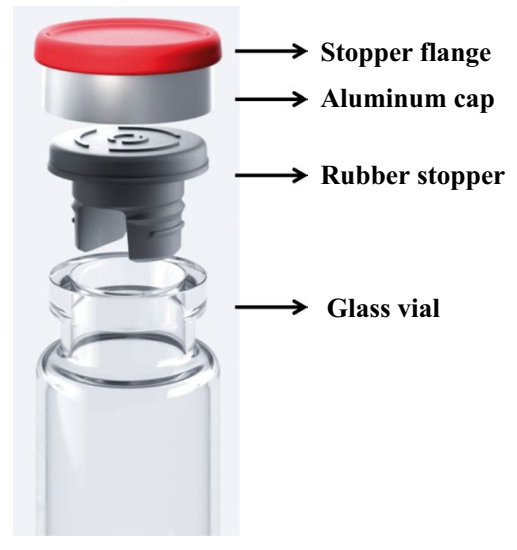

Fig. 2 Glass vial and closure system for primary packaging of coronavirus disease vaccines consisting of a rubber stopper, aluminum cap, and stopper flange

the carbon footprint and sustaining extreme storage temperatures such as -60 to $-90^{\circ} \mathrm{C}$ (Pfizer-BioNTech) (Hogue 2020). Researchers at Corning have developed coated aluminosilicate valor glass vials that have added advantages over borosilicate glass. The ion exchange process is used to produce valor glass vials, which helps in reducing breakage, particulate contamination, and cracks. In contrast, the coating helps in lowering the coefficient of friction and cosmetic flaws. Corning's registered product Valor ${ }^{\circledR}$ meets the United States Pharmacopeia type I hydrolytic criteria with low extractable concentrations and can run the fill lines at higher operational efficiency, i.e., greater than $80 \%$ compared to conventional glass vials (Shanley 2020).

The US-based pharmaceutical industry, $\mathrm{SiO} 2$ Materials Science, has a unique solution for ULT applications. They have developed a novel hybrid material, cyclic olefin polymer with nanolayer glass as the inner layer by using plasmaenhanced chemical vapor deposition (Hogue 2020; Weikart and Langer 2020). The structure and layer-wise assembly of the hybrid material vial are shown in Fig. 3. Typical standards for shape, size, dimensions, and performance requirements for injection vials made of glass tubing, closures, and aluminum caps are set by International Organization for Standardization (ISO) 8362-4:2011 (ISO 2011). Some of the standard dimensions acquired by the pharmaceutical industries for type I molded glass vials are listed in Table 1. Briefly, the global glass vial industry is facing invincible upsurge in demand even after producing 50 billion vials annually.

\section{Syringes}

Along with vials, syringes are also crucial in the vaccination process from a packaging perspective. Previously, conventional disposable syringes were used to inject 


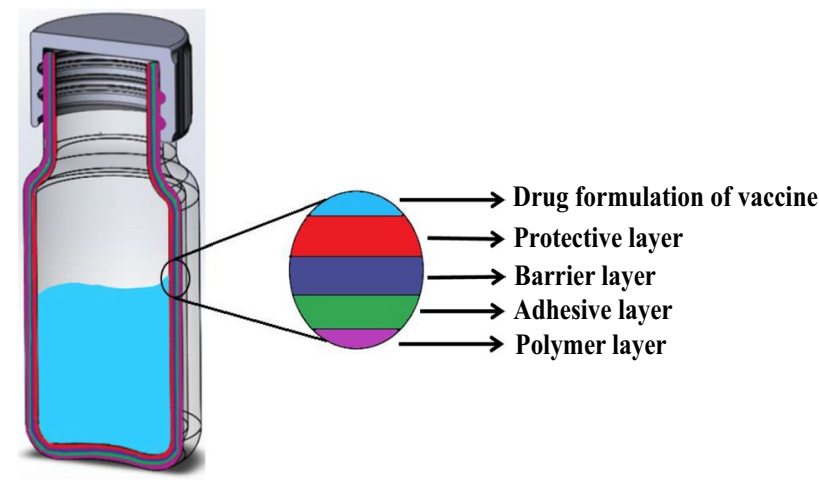

Fig. 3 Multilayered structure of filled $\mathrm{SiO}_{2}$ smart vial made with hybrid material consisting of a protective nanoglass layer along with cyclic olefin polymeric layer

Table 1 Standard dimensions for type I molded glass vials by vaccine manufacturers, as per the International Organization for Standardization. Source: SGD (2018)

\begin{tabular}{llllll}
\hline $\begin{array}{l}\text { Nominal } \\
\begin{array}{l}\text { Volume } \\
(\mathrm{ml})\end{array}\end{array}$ & $\begin{array}{l}\text { Brim full } \\
\text { volume } \\
(\mathrm{ml})\end{array}$ & $\begin{array}{l}\text { Weight } \\
(\mathrm{g})\end{array}$ & $\begin{array}{l}\text { Height } \\
(\mathrm{mm})\end{array}$ & $\begin{array}{l}\text { Neck } \\
\text { finish } \\
(\mathrm{mm})\end{array}$ & $\begin{array}{l}\text { Outer } \\
\text { diameter } \\
(\mathrm{mm})\end{array}$ \\
\hline 5 & 7 & 14 & 41.30 & 20 & 20.80 \\
8 & 10 & 16 & 46.80 & 20 & 23.00 \\
10 & 15 & 21 & 53.50 & 20 & 25.40 \\
15 & 17 & 24 & 58.80 & 20 & 26.50 \\
20 & 26 & 29 & 58.00 & 20 & 32.00 \\
\hline
\end{tabular}

drugs; however, the lack of technological advancement, production capacity, economic necessity, and cultural resistance to waste subsequently aided to reuse the same. To avoid reusability, the WHO believed that there should be a physical barrier to the reuse of syringes and requested the design of auto disable syringes in 1986. The purpose of the auto disable syringe is to prevent the transmission of blood-borne pathogens, to prevent reuse, and to prevent resale after use (Lloyd and Milstien 1999). The model auto disable syringes before and after use are shown in Fig. 4. The United Nations International Children Emergency Fund (UNICEF) stockpiles auto disable syringes for the COVID-19 Vaccines Global Access (COVAX) campaign as a precautionary measure to ensure that the waste does not reach children. There have been a few instances where children have used them as toys. To avoid this, UNICEF is procuring 1 billion auto-disable syringes by the end of 2021 (UNICEF 2021). Different sizes of syringes and needles are needed for different vaccines, and the selection criteria depend on the dosage capacity and injection sites, such as subcutaneous, intramuscular, and intradermal. Typical injection syringe range includes $0.3,0.5,1.0,2.0$, and $5.0 \mathrm{~mL}$ (Cancaster 2015).

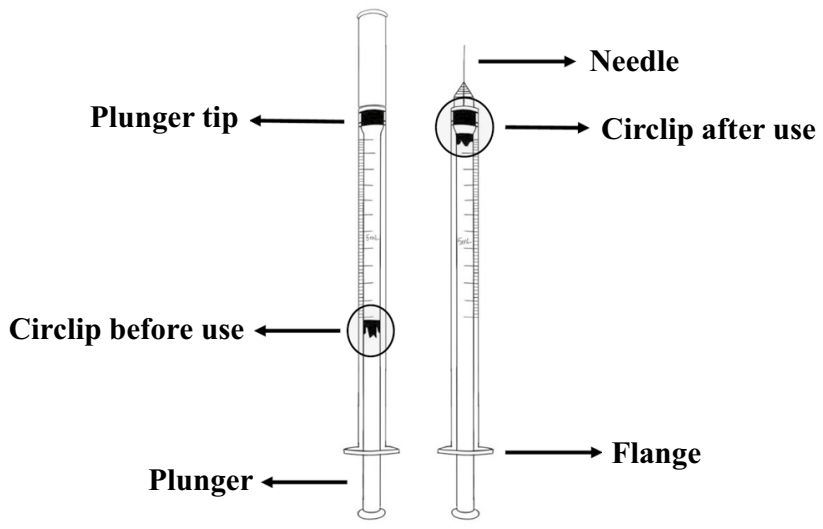

(a) (b)

Fig. 4 Single-use auto-disable syringe for coronavirus disease vaccine doses and components $\mathbf{a}$ before use and $\mathbf{b}$ after use

\section{Fused quartz vials}

Fused quartz vials, made up of $99.99 \%$ pure silicon dioxide with an exceptionally inert nature, provide a ready-to-use format for fill-finish operations. The largest fused quartz vial producer, Momentive Technologies, has recently introduced its ultra-high purity vials (Pur Q®) to the Stevanto Group EZ-fill@ format. In addition to its excellent inertness, a low coefficient of thermal expansion makes Pur Q ${ }^{\circledR}$ extremely resistant to thermal shock, thus making it suitable for a wide range of storage temperatures (Stevanato 2020).

\section{Stoppers and seals}

Every vaccine candidate using vials relies on stoppers and seals. Stoppers protect from environmental impacts, whereas seals are critical for ensuring drug protection, container closure integrity, and safety. A protective fluoropolymer barrier layer applied on an elastomer (latex-free) acts as a barrier to the migration of elastomer components to the drug. Stoppers, a part of the closure system, can be autoclaved prior to dispatch, provided as a sterile component along with vials, or can be sterilized at fill-finish lines (West 2021; Shanley 2020). For example, Janssen has used Chlorobutyl rubber stopper along with aluminum crimp and a blue plastic flipoff for its COVID-19 vaccine packaging. Some of commercially available COVID-19 vaccines are shown in Table 2.

\section{Packaging system for vaccines distribution}

The packaging system for distribution plays a predominant role in delivering the vaccines to the ultimate consumers in suitable condition and at right time. A typical packaging system for distribution includes secondary and tertiary 
Table 2 Commercially available coronavirus disease vaccines with packaging capacity, dimensions and storage conditions

\begin{tabular}{|c|c|c|c|c|c|c|c|}
\hline $\begin{array}{l}\text { Vaccine's com- } \\
\text { mercial name }\end{array}$ & $\begin{array}{l}\text { Vaccine manu- } \\
\text { facturer }\end{array}$ & $\begin{array}{l}\text { Primary pack- } \\
\text { aging capacity } \\
(\mathrm{ml})\end{array}$ & $\begin{array}{l}\text { Primary pack- } \\
\text { aging material }\end{array}$ & $\begin{array}{l}\text { Stopper/ } \\
\text { seal material }\end{array}$ & $\begin{array}{l}\text { Storage condi- } \\
\text { tions }\end{array}$ & $\begin{array}{l}\text { Refrigeration } \\
\text { storage dura- } \\
\text { tion }\end{array}$ & $\begin{array}{l}\text { Secondary dimen- } \\
\text { sions }\end{array}$ \\
\hline 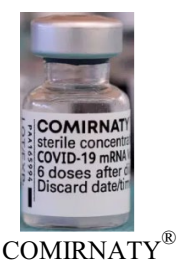 & $\begin{array}{l}\text { Pfizer Inc- } \\
\text { BioNTech, } \\
\text { United States of } \\
\text { America }\end{array}$ & 2 & $\begin{array}{l}\text { Clear glass vial } \\
\text { (Type 1) }\end{array}$ & $\begin{array}{l}\text { Synthetic } \\
\text { bromobutyl } \\
\text { rubber/ } \\
\text { Flip-off plastic } \\
\text { cap with Alu- } \\
\text { minum }\end{array}$ & $\begin{array}{l}-80 \text { to }- \\
60{ }^{\circ} \mathrm{C} \\
2 \text { to } 8{ }^{\circ} \mathrm{C}\end{array}$ & $\begin{array}{l}6 \text { months } \\
5 \text { days }\end{array}$ & $\begin{array}{l}9^{\prime \prime} \mathrm{L} \times 9^{\prime \prime} \mathrm{W} \times 1.7^{\prime \prime} \\
\mathrm{H}\end{array}$ \\
\hline 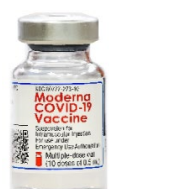 & $\begin{array}{l}\text { ModernaTX, } \\
\text { Inc } \\
\text { United States of } \\
\text { America }\end{array}$ & 5 & $\begin{array}{l}\text { Clear glass vial } \\
\text { (Type 1) }\end{array}$ & $\begin{array}{l}\text { Chlorobutyl } \\
\text { rubber/ } \\
\text { Aluminum with } \\
\text { flip off plastic } \\
\text { cap }\end{array}$ & $\begin{array}{l}-25 \text { to }-15^{\circ} \mathrm{C} \\
2 \text { to } 8^{\circ} \mathrm{C}\end{array}$ & $\begin{array}{l}6 \text { months } \\
30 \text { days }\end{array}$ & $\begin{array}{r}5.5^{\prime \prime} \mathrm{L} \times 2.2^{\prime \prime} \\
\mathrm{W} \times 2.5^{\prime \prime} \mathrm{H}\end{array}$ \\
\hline Moderna & & & & & & & \\
\hline Janssen & $\begin{array}{l}\text { Janssen-Cilag } \\
\text { International } \\
\text { N.V., } \\
\text { Belgium }\end{array}$ & 2.5 & $\begin{array}{l}\text { 2R clear glass } \\
\text { vial (Type } 1 \text { ) }\end{array}$ & $\begin{array}{l}\text { Chlorobutyl } \\
\text { with fluoropol- } \\
\text { ymer coated } \\
\text { surface/ } \\
\text { Aluminum } \\
\text { crimp with a } \\
\text { blue plastic } \\
\text { flip-off }\end{array}$ & $\begin{array}{l}-25 \text { to }-15^{\circ} \mathrm{C} \\
2 \text { to } 8{ }^{\circ} \mathrm{C}\end{array}$ & $\begin{array}{l}24 \text { months } \\
3 \text { months }\end{array}$ & $\begin{array}{r}3.66^{\prime \prime} \mathrm{L} \times 1.5^{\prime \prime} \\
\mathrm{W} \times 2.13^{\prime \prime} \mathrm{H}\end{array}$ \\
\hline 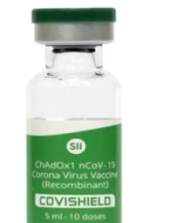 & $\begin{array}{l}\text { Serum Institute } \\
\text { of India Pvt. } \\
\text { Ltd, } \\
\text { India }\end{array}$ & 2,5 & $\begin{array}{l}\text { Clear glass vial } \\
\text { (Type 1) }\end{array}$ & $\begin{array}{l}\text { Elastomeric/ } \\
\text { Aluminum } \\
\text { flip-off plastic } \\
\text { button }\end{array}$ & 2 to $8{ }^{\circ} \mathrm{C}$ & 6 months & $\begin{array}{c}7.28^{\prime \prime} \mathrm{L} \times 3.74^{\prime \prime} \\
\mathrm{W} \times 2.36^{\prime \prime} \mathrm{H}\end{array}$ \\
\hline COVISHIELD $^{\mathrm{TM}}$ & & & & & & & \\
\hline 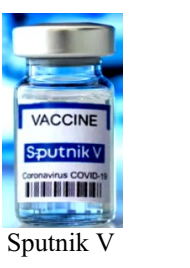 & $\begin{array}{l}\text { Gamaleya } \\
\text { National } \\
\text { Research } \\
\text { centre, } \\
\text { Russia }\end{array}$ & & - & - & $\begin{array}{l}-18.5^{\circ} \mathrm{C} \text { (liq- } \\
\text { uid form) } \\
2 \text { to } 8{ }^{\circ} \mathrm{C} \\
\text { (dry form) }\end{array}$ & - 2 months & - \\
\hline COVAXIN & $\begin{array}{l}\text { Bharat Biotech, } \\
\text { India }\end{array}$ & 5,10 & $\begin{array}{l}\text { Transparent } \\
\text { glass vial } \\
\text { (Type 1) }\end{array}$ & $\begin{array}{l}\text { Butyl rubber/ } \\
\text { Flip off plastic } \\
\text { cap with Alu- } \\
\text { minum }\end{array}$ & 2 to $8^{\circ} \mathrm{C}$ & 6 months & $\begin{array}{c}3.94^{\prime \prime} \mathrm{L} \times 3.94^{\prime \prime} \\
\mathrm{W} \times 2.16 \mathrm{H}\end{array}$ \\
\hline
\end{tabular}

packaging, and cushioning materials to protect the glass vials (primary package) from breaks and cracks during transport and storage. A cold chain is required for some vaccine candidates to safeguard the vaccine until it reaches the injection point. Table 3 provides an overview of the packaging systems involved and materials used at each level of vaccine packaging.

\section{Secondary packaging}

Once the vaccines are produced at the manufacturers' facility, they need to be shipped to multiple locations. Vials/ ampoules/leaflets are packed in secondary cartons to optimize their volume and weight for transport and storage. The number of primary packaging units per secondary carton 
Table 3 Types of materials used at each level of vaccine packaging

\begin{tabular}{ll}
\hline Components of vaccine packaging & Materials \\
\hline Primary packaging (Vial) & $\begin{array}{c}\text { Clear glass type-I, cyclic olefin polymer with nanolayer glass, } \\
\text { coated aluminum silicate valor glass } \\
\text { Rubber stopper and crimped aluminum seal }\end{array}$ \\
Closure & Paper \\
Labeling and leaflet & Fiberboard box, plastic trays with vial trays \\
Secondary packaging & Corrugated fiberboard box, thermally insulated plastic containers \\
Tertiary packaging &
\end{tabular}

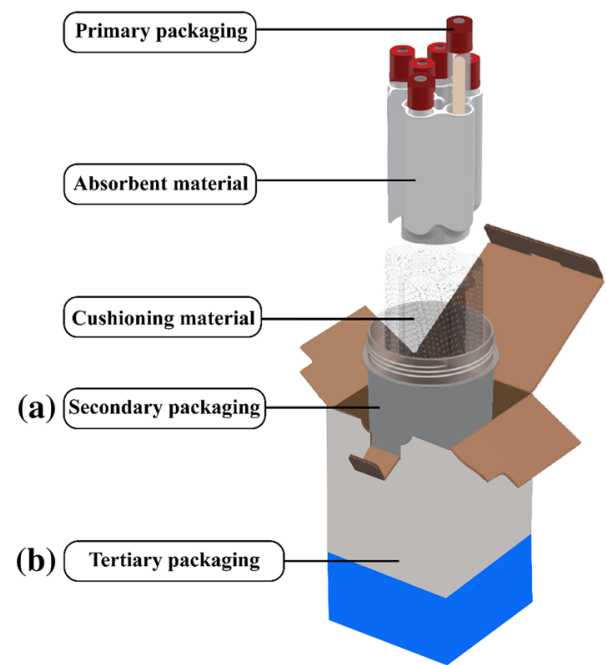

Fig. 5 Typical packaging system for vaccines containing a Secondary packaging and $\mathbf{b}$ Tertiary packaging. Adapted and modified from INTELSIUS:Zhang et al. (2020)

can be determined based on the domestic and international supply. Assumptions can be made based on existing vaccine packaging patterns; however, a clear set of guidelines have not been provided for upcoming vaccines in the past (WHO 2009). Secondary packaging can be influential in terms of reducing volume, cost-saving, minimizing logistical burden, and ultimately reducing the carbon footprint. Two decades ago, the WHO was requested for the strengthening of packaging standards by changing the secondary carton capacity from 5 to 10 primary units to $50-100$ primary units per carton. Apparently, this could reduce shipping costs, minimize dead space, and reduce the number of cold boxes required (Newland 2011). A secondary packaging model for vaccines is shown in Fig. 5a. The following examples show the dimensions and capacity of secondary packaging units developed by recent Covid-19 vaccine candidates (Holm and Poland 2021). The secondary carton dimensions for other vaccine candidates are given in Table 2.

1. Pfizer vaccine comes in a $2 \mathrm{~mL}$ vial with a secondary carton containing 195 primary packaging units with an approximate size of L 8.13" X W 8.13" x H 1.75".

2. Moderna's mRNA vaccine contains 10 primary packaging units for each secondary carton with an approximate size of L 5.5" x W 2.2" x H 2.5"

The Vaccine Presentation and Packaging Advisory Group (VPPAG) recommends that the vaccine manufacturers prepare formats that could minimize the number of steps and eliminate errors during preparation and administration. The VPPAG recommendations are listed in Table 4. For secondary packaging units, vials packed in rectangular arrays with 5 or 10 vial units along with standardized diameter

Table 4 Vaccine preparation and packaging advisory group recommendations on vaccine packaging system and dimensions. Source: (WHO 2009)

\begin{tabular}{|c|c|}
\hline Packaging parameter & Recommendations by vaccine preparation and packaging advisory group \\
\hline Secondary packaging & $\begin{array}{l}\text { Rectangular arrays with internal dividers are encouraged for secondary packaging of vials } \\
\text { A standard format of } 100 \text { vials in an array of } 10 \times 10 \text { or } 10 \text { vials in a } 5 \times 2 \text { array is being followed } \\
\text { The dimensions should accommodate vials and dividers }\end{array}$ \\
\hline Tertiary packaging & $\begin{array}{l}\text { Fiberboard cartons are preferable for tertiary packing } \\
\text { Multiples of } 100 \text { vials are packed in one tertiary unit for ease in counting } \\
\text { Legit dimensions of } 1.2 \mathrm{~m} \times 0.8 \mathrm{~m} \text { or } 1.0 \mathrm{~m} \times 1.2 \mathrm{~m} \text { are set to avoid overhanging with a gross weight not } \\
\text { exceeding } 25 \mathrm{kgs} \text { per unit }\end{array}$ \\
\hline $\begin{array}{l}\text { Materials including primary } \\
\text { packaging and delivery } \\
\text { device }\end{array}$ & $\begin{array}{l}\text { Select the source materials that reduce the impact on the environment when disposed off } \\
\text { Reduce, Reuse and Recycle are the } 3 \mathrm{R} \text { 's to be followed during the end-of-life handling of materials } \\
\text { Secondary and tertiary materials, including labels, should be long term resistant to condensation and standard } \\
\text { relative humidity ( } 75 \% \text { Relative Humidity) }\end{array}$ \\
\hline
\end{tabular}


and height could provide better dimensional harmonization. The secondary carton size should be optimally decided to accommodate vials, packaging inserts, and internal dividers (WHO 2009).

\section{Tertiary packaging}

Tertiary packaging is the most prevalent packaging for the shipping and transportation of vaccines. They have numerous advantages over other forms of packaging materials. For international shipments, outer-insulated boxes are used as shipping units, either alone or as pallet shippers. They are characterized by physical integrity, can retain their properties, and can withstand mechanical manipulation, repeated manual handling, and various climatic conditions. According to WHO recommendations, insulated boxes should weigh less than $50 \mathrm{~kg}$, as they can be handled manually at airports and other distribution centers (WHO 2005). These boxes are not seen by consumers as retailers remove them before they reach the point of end use. Generally, cardboards, plane boxes, and shrink wraps are used in tertiary packaging (Ankur 2018). A model of the tertiary packaging is shown in Fig. 5b. The recommendations made by the VPPAG are as follows:

1. It should be tested and qualified to withstand anticipated loads, shocks, and vibrations during transportation and distribution.

2. Dimensional harmony is vital for stock management, and tertiary cartons can be helpful.

3. It should be a more convenient and robust stock-keeping unit than the secondary packaging unit.

4. The width of the tertiary cartons must be in accordance with the available shelf width of cold rooms and freezer rooms, i.e., $45-60 \mathrm{~cm}$.

5. To take into account the stock, contents inside the tertiary packaging must be arranged in multiples of 50 or 100 units.

6. The European Economic Community (EEC) Council Directive 90/269/EEC states that the maximum weight of a tertiary carton should be in such a way that a person can lift it safely.

7. The tertiary carton dimensions are selected as per ISO standardized pallets with dimensions $1.2 \mathrm{~m} \times 0.8 \mathrm{~m}$ or $1.0 \mathrm{~m} \times 1.2 \mathrm{~m}$ so that these can be efficiently stacked without overlapping individual pallet's footprint.

Briefly, secondary packaging contributes a lot in optimizing the volume utilization by increasing no. of primary units from 5-10 to 50-100. The reduction in weight without compromising the other functions of tertiary packaging could benefit environment.

\section{Labeling system for vaccine package}

"Labelling makes the invisible visible, but an improper label can put the patients' life in jeopardy." An unambiguous label is indispensable rather than consequential for a successful immunization program. The labeling system contains primary container labels, secondary carton and tertiary container labels, leaflets, packaging inserts, bar codes, quick response codes and vaccine vial monitors (VVMs).

\section{Primary container label}

A primary container label is vital in identifying the right drug, its mode of injection, and the minimum quantity required per dose. The clearer the label, the more errorfree is the vaccination program. According to a previous survey (Path 2021), approximately $94 \%$ of healthcare providers agreed that vaccine package labels are crucial for their work. This shows the importance of the label and urges vaccine manufacturers to follow the relevant standards. The vaccine presentation and packaging advisory group (VPPAG) had come across two genuine labeling issues: minimum font size for legibility and expiry date format. Based on the analysis conducted, this advisory group recommended the WHO for improvements and standardization in future vaccine labels. As text legibility is directly related to the quantity of text, the advisory group has recommended standardizing and minimizing information on primary packaging labels. The use of multiple languages further decreases the label's space and forces manufacturers to use the minimum font size. The use of different expiry date formats on labels has caused ambiguity among consumers in the past. The major problem is with numerical formats such as 02-04-12, which can be treated as both February 04 and April 02. This can be avoided by standardizing an all-numeric format for the expiry date, MM-YYYY, as presented in Table 5. Vaccine labels should not limit the ability of healthcare providers to see through the contents of the vials. To avoid this, manufacturers are requested to provide a minimum viewing area for the contents in the vials (WHO 2009).

Vials are widely accepted as the primary packaging material for COVID-19 vaccines. The WHO has been preparing and issuing model labels as guidance to manufacturers to standardize the label requirements for the COVAX program. It has issued a working position for a vial label, as shown in Fig. 6. It should contain the name of the vaccine, the manufacturer's name, storage conditions, manufacturing, and expiry date, batch/lot number, volume per dose, doses per container, and leaflet or 
Table 5 Vaccine preparation and packaging advisory group recommendations on vaccine labeling. Source: (WHO 2009)

\begin{tabular}{|c|c|}
\hline Labeling parameter & Recommendations by Vaccine preparation and packaging advisory group \\
\hline Primary container labels & $\begin{array}{l}\text { Minimum requirements to be printed like product name, expiry date, dosage, storage conditions are decided with the } \\
\text { available minimum viewing area } \\
\text { Standard numeric format for expiry date (MM-YYYY) is to be followed } \\
\text { Use standard and generic names in minimum font size for label legibility }\end{array}$ \\
\hline $\begin{array}{l}\text { Secondary carton and ter- } \\
\text { tiary packaging labels }\end{array}$ & $\begin{array}{l}\text { Labeling is recommended at least on two opposite surfaces while three surfaces is given preference } \\
\text { Only the static information is printed on two faces, whereas dynamic information is sufficed for one face }\end{array}$ \\
\hline Barcodes & $\begin{array}{l}\text { Printing on all levels of packaging except for primary is endorsed } \\
\text { It should include Global Trade Item Number, unit number, and expiry date committing to General Specifications } \\
\text { standards }\end{array}$ \\
\hline Package Inserts & $\begin{array}{l}\text { Advised to supply according to World Health Organization format } \\
\text { Along with this, a leaflet is encouraged to be available for sharing of knowledge about the vaccine in different lan- } \\
\text { guages }\end{array}$ \\
\hline
\end{tabular}

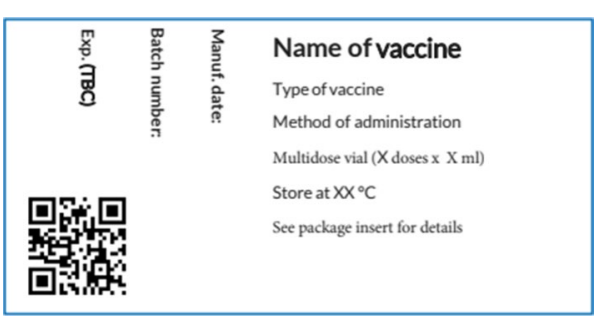

Fig. 6 Model label for vials for coronavirus disease vaccines, according to WHO guidelines. Adapted from WHO (2020b)

package insert for other details. To summarize, a primary container label is essential for any medical product. A label with a clear understanding of necessary information is a good fit.

\section{Secondary and tertiary packaging labels}

Secondary and tertiary carton labels ease the process of identification and distinguish similar types of vaccines during storage and distribution, thus minimizing the errors in selecting a product and can help in accurate stock counting and management. To achieve the abovementioned targets, secondary and tertiary cartons must be labeled at least on two opposite faces, as per the guidelines for labeling of vaccines, proposed amendments to the Technical Report Series (TRS) 822, and requirement for prequalified products. The printed content must contain both static and dynamic information, such as bar codes and quick response codes that can be printed on one face only (WHO 2009). To unify the labeling system for the immunization program, the WHO has recommended the manufacturers to follow model carton labeling as shown in Fig. 7.

\section{Package inserts}

The package insert is a part of the labeling system, as complete information about the product and its use cannot be specified on the primary package. Therefore, vaccine manufacturers should supply mandatory information such as product information, prescription information, and risks involved with the drug. Package inserts contain product information in an advanced technical language that might confuse healthcare providers and patients. To avoid such ambiguity, a simplified fact sheet called the patient information leaflet (PIL) can be additionally supplied by the manufacturer. PIL contains basic information regarding prescription and administration routes translated in the local language, based on the country to which it is exported, to reduce the risk of administrative error. Regulatory requirements are necessary to monitor the location and content of package inserts. Often, the use of package inserts makes secondary cartons bulky, leading to increased disposable volume. To overcome waste disposal and increase secondary packaging volume, patient information leaflets should be available in digital formats and can be downloaded online from the WHO vaccine database (WHO 2009; Thornton 2003). Manufacturers are recommended to follow the standard WHO format for package inserts to avoid such ambiguity at the grassroots level. Different countries follow their own regulations. According to the European Commission Regulation No. $726 / 2004$, all approved medicinal products should contain both patient information leaflet and a summary of product characteristics (Dijk et al. 2014). In contrast, USFDA has brought the Fair packaging and labeling Act-1966 to accurately label the consumer products such as foods, drugs, cosmetics, and medical devices. Along with that the code of federal regulations (CFR)-Title 21 for food and drugs, part 201, Sect. $201.56 \& 201.57$ - specifies the latest requirements for "Content and format of labeling for 


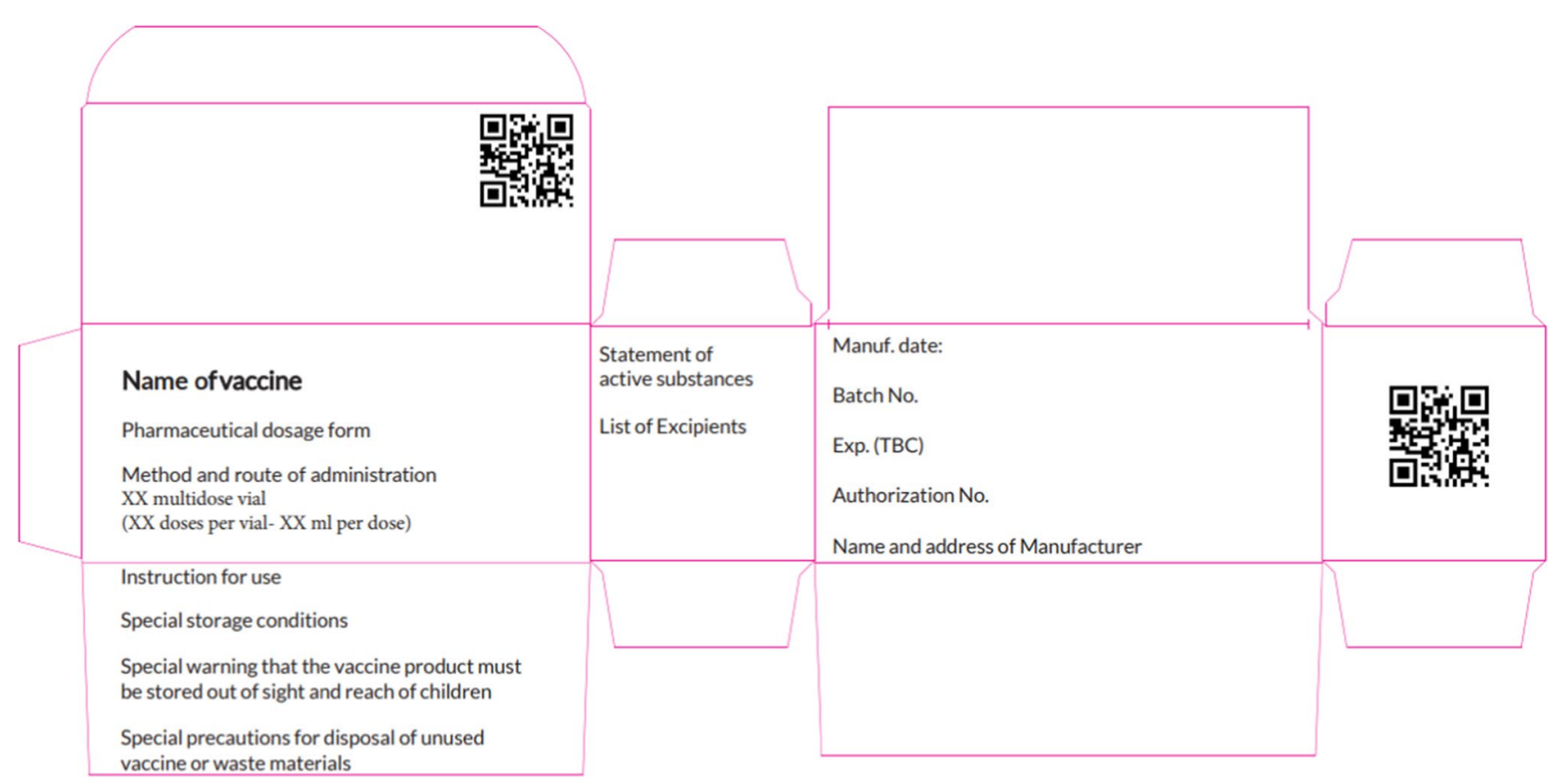

Fig. 7 Model label for cartons for coronavirus disease vaccines according to WHO guidelines. Adapted from WHO (2020c)

human prescription drug and biological products" (Watson and Barash 2009; Nathan and Vider 2015).

\section{Bar codes}

Barcodes and quick response codes come under the category of data carriers, which are one way readable. They facilitate information about the product in an electronic version (GS1 2021). When read with the help of scanners, the data are analyzed digitally and reproduced to the consumer. In the case of vaccines, this technology is being used as a supplement for printed information about the product. Barcodes are linear in nature and simply store information about the vaccine expiration date and lot number (WHO 2020d). The components of a linear barcode include a 12-digit serial number called the global trading identification number (GTIN) and a series of bars and spaces. The GTIN has a deciphered meaning: the first two digits give the country code, and the following digits provide details about the manufacturer, product, and batch (GTIN 2015). They are recommended for use in primary and secondary packaging. quick response codes are 2D barcodes that are designed as a square modulus arranged within a perimeter (Kuswandi and Jumina 2020). They store every piece of information printed on primary packaging and packaging inserts, including the route of administration, date of manufacture/expiration, batch number, doses per vial, dosage, temperature requirements, and sometimes information about the manufacturer for traceability purposes (WHO 2020d). It is highly suggested that they can be added to secondary packaging as well. Recently, the Centers for
Disease Control and Prevention has been encouraging 2D barcodes to be added to the vaccine information statement for the COVID-19 vaccine to help both patients and practitioners (CDC 2021).

\section{Vaccine vial monitors}

Incorporation of vaccine vial monitors into primary packaging is considered a preferred characteristic for primary packaging. It is a type of sensor that helps determine the vaccine's history of any exposure to cumulative heat over time, as shown in Fig. 8. It is made of a heat-sensitive material, comes in a small circle with a square inside, and is printed on the label or cap of the vaccine. With the darkened color of the inner square compared to the outer circle, vaccine vial monitors indicates that the vial has been exposed to critical temperatures and should no longer be used. This visual indication successfully decreases the risk of administration of sub-potent vaccines. The color change is a continuous process and is irreversible, making them more reliable. Vaccine

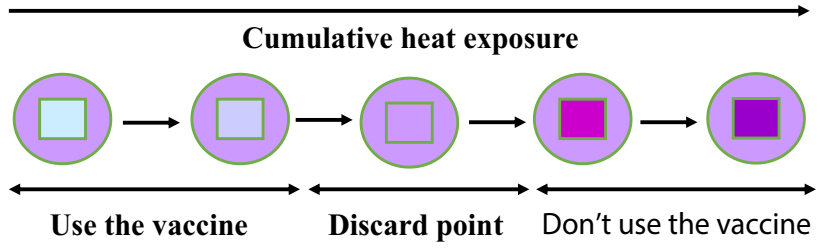

Fig. 8 Indication of vaccine's history upon exposure to cumulative heat by vaccine vial monitors 
vial monitors are highly recommended by the WHO and UNICEF considering the temperature-sensitive nature of the COVID-19 vaccine (WHO 2009).

\section{Anti-counterfeiting features in vaccine packaging}

The pharmaceutical industry is more vulnerable to counterfeit medical products. A survey conducted by International Data Corporation (IDC) in June 2020 revealed that approximately $70 \%$ of manufacturers agreed on the vulnerability of their supply chain, if COVID-19 continued for a couple of months and approximately $75 \%$ of companies agreed to an increase in theft, diversion, or counterfeiting of vaccines, test kits, and antivirals (Forcinio 2021). Vaccine manufacturers should be aware of the fake COVID-19 vaccines entering the market. A study conducted by the Authentication Solution Providers Association of India revealed that counterfeiters do not produce vaccines, they just fool people by duplicating the vaccine packaging while putting harmful or inactive contents inside. A recent Interpol global alert to law enforcement agencies in 194 member countries against organized networks targeting COVID-19 vaccines provides evidence of the severity of the situation (Outlook 2021).

In order to curb counterfeiting, laws, and regulations have been formulated by various agencies such as the European Union's Falsified Medicine Directive and the US's Drug Supply Chain Security Act (Forcinio 2021). The WHO also constituted a task force unit in 2006, The International Medical Products Anti-Counterfeiting Taskforce (IMPACT), to fight against the multi-million-dollar illegal trade of counterfeit drugs and vaccines (WHO 2020e).

\section{Anti-counterfeiting measures}

With advancements in technologies and maintaining consumer safety as a concern, pharmaceutical companies are focusing on tailor-made anti-counterfeit solutions. A multilevel security approach with a tailor-made use, along with digital and analog techniques verified by multiple stakeholders within the supply chain, is necessary for anti-counterfeit products (Forcinio 2021). Labeling techniques, such as tamper-evident labels and holograms, can help reduce the counterfeiting of a product. Other methods such as radio frequency identification devices and near-field communication tags could also help fight against counterfeiters. Magnetic ink is another vital tool developed by Inspectron, which prints a barcode that the naked eye cannot read. The serialized code printed inside a carton or under a label can be read from a $2 \mathrm{~mm}$ distance by a specific reader. TruTag Technologies has a unique product-level authentication technology, on-dose, which uses edible microparticles combined with smart medicine, and confirms product authenticity. Another technique from Applied DNA Sciences received the nod from USFDA to its molecular tagging technology, which gives immutable identity to both dose and packaging. AlpVision's COVID-19 initiative provides a new tool, Cryptoglyph digital security, to pharmaceutical companies. Cryptoglyph is invisible to the human eye and can only be authenticated by a smartphone, which connects to AlpVision's brand monitoring system for real-time monitoring of product authentication (Forcinio 2021; Bansal et al. 2013). Overall, nearly $70 \%$ of existing supply chains are vulnerable to counterfeiting. There is a need to establish dedicated regulatory bodies, more stringent actions, and security features to be added to anti-counterfeit medical products.

\section{Conclusion}

Packaging is a potential tool for immunization programs. The unforeseen challenges related to the safe packaging and distribution of the COVID-19 vaccine have created an opportunity for packaging developers to strategically develop and innovate vaccine packaging systems. Advancements in developing new materials and access to cuttingedge technology have given vaccine developers a huge scope in providing vaccines in an effective and affordable manner. Vials used in traditional vaccine packaging have seen a new phase of development by the introduction of hybrid materials, such as coated aluminosilicate valor glass and cyclic olefin polymer with a glass nanolayer. Another challenge that needs to be addressed is underlining a new set of regulations for better protection of vaccines in terms of packaging, labeling, and distribution. This requires synergistic efforts from the Governments, WHO, and other governing bodies. Technologies such as the Internet of Things, blockchain technology, and artificial neural networks can also be used to monitor real-time data and implement cold chain distribution of vaccines. Finally, advanced studies on the prospective application of intelligent packaging should also be conducted to prevent any crisis in the future.

Acknowledgements Author Dakuri Ramakanth would like to thank the Ministry of Human Resources and Development (MHRD), Government of India, for providing financial support to carry out this research work.

Authors contribution The authors conceptualized the study design jointly. DR searched for and resolved conflicts, writing the first draft. SS and PKM charted the data. YSL and KK. Gaikwad led the analysis, writing and incorporated critical feedback from all authors.

\section{Declaration}

Conflict of interest The authors declare that they have no conflict of interest. 


\section{References}

Ankur Chaudhary (2018) Packaging of pharmaceutical products. Pharma guideline. https://www.pharmaguideline.com/2018/ 03/packaging-of-pharmaceutical-products.html. Accessed 08 Apr 2021

Bansal D, Malla S, Gudala K, Tiwari P (2013) Anti-counterfeit technologies: a pharmaceutical industry perspective. Sci Pharm 81:1-14. https://doi.org/10.3797/scipharm.1202-03

CDC (2021) Centre for disease control and prevention. Barcodes on vaccine information statements. https://www.cdc.gov/vaccines/ hcp/vis/barcodes.html. Accessed 08 Apr 2021

Cancaster B. (2015) Syringe and needle selection guide. https:// www.vitalitymedical.com/blog/selecting-syringes-and-needl es.html. Accessed 08 Apr 2021

Chen B, Jia P, Han J (2021) Role of indoor aerosols for COVID-19 viral transmission: a review. EnvironChem Lett. https://doi.org/ 10.1007/s 10311-020-01174-8

Choi H, Chatterjee P, Coppin JD et al (2021a) Current understanding of the surface contamination and contact transmission of SARSCoV-2 in healthcare settings. Environ Chem Lett. https://doi. org/10.1007/s10311-021-01186-y

Choi H, Chatterjee P, Lichtfouse E et al (2021b) Classical and alternative disinfection strategies to control the COVID-19 virus in healthcare facilities: a review. Environ Chem Lett. https://doi. org/10.1007/s10311-021-01180-4

Dijk L, Monteiro SP, Vervloet M, de Bie J, Raynor DT (2014) Study on the package leaflets and the summaries of product characteristics of medicinal products for human use. PIL's Study. European Union 1-141

Fauci AS, Lane HC, Redfield RR (2020) Covid-19-Navigating the uncharted. New Engl J Med. https://doi.org/10.1056/NEJMe 2002387

Forcinio H (2021) Countering counterfeiters and diverters. Pharmaceutical Technology 45(2): 43-45. https://www.pharmtech. $\mathrm{com} / \mathrm{view} /$ countering-counterfeiters-and-diverters. Accessed 08 Apr 2021

GS1 (2021) GS1 General specifications. 15: 490. https://www.gs1. org/sites/default/files/docs/barcodes/GS1_General_Specificat ions.pdf. Accessed 08 Apr 2021

GTIN (2015) Global trade item number. Barcode 101: Guide to barcode symbologies. https://www.gtin.info/barcode-101/. Accessed 08 Apr 2021

Gaikwad KK, Singh S, Ajji A (2019) Moisture absorbers for food packaging applications. Environ Chem Lett 17(2):609-628. https://doi.org/10.1007/s10311-018-0810-z

Gaikwad KK, Singh S, Lee YS (2018) Oxygen scavenging films in food packaging. Environ Chem Lett 16:523-538. https://doi.org/ 10.1007/s10311-018-0705-Z

Han J, Zhang X, He S et al (2021) Can the coronavirus disease be transmitted from food? A review of evidence, risks, policies, and knowledge gaps. Environ Chem Lett 19:5-16. https://doi. org/10.1007/s 10311-020-01101-x

Haynes BF, Corey L, Fernandes P, Gilbert PB, Hotez PJ, Rao S, Arvin A (2020) Prospects for a safe COVID-19 vaccine. Sci Translational Med 12(568):0948. https://doi.org/10.1126/scitr anslmed.abe 0948

He S, Han J, Lichtfouse E (2021) Backward transmission of COVID19 from humans to animals may propagate reinfections and induce vaccine failure. Environ Chem Lett 19:763-768. https:// doi.org/10.1007/s10311-020-01140-4

Hogue C. (2020) Vital vials for vaccines. C\&EN Glob. Enterp., 98 (37): 24-25, doi:https://doi.org/10.1021/cen- 09837-feature3. https://doi.org/10.1021/cen-09837-feature3. Accessed 08 Apr 2021
Holm MR, Poland GA (2021) Critical aspects of packaging, storage, preparation, and administration of mRNA and adenovirus-vectored COVID-19 vaccines for optimal efficacy. Vaccine 39(3):457-459. https://doi.org/10.1016/j.vaccine.2020.12.017

IMD (2020) Institute for management development. There will be no COVID-19 vaccine without theright packaging. Available via DIALOG. https://www.imd.org/news/updates/no-covid-vaccinewithout-right-packaging/. Accessed 08 Apr 2021

INTELSIUS (2020) Cold chain packaging solutions-PATHOPAK. Avialable via DIALOG: https://intelsius.com/products/sample-trans port/pathopak/. Accessed 26 Apr 2021

ISO (2011) International standard organization. Injection containers and accessories- Part 4: Injection vials made of moulded glass. https://www.iso.org/obp/ui/\#iso:std:iso:8362:-4:ed-3:v1:en. Accessed 08 Apr 2021

Kuswandi B, Jumina (2020) Active and intelligent packaging, safety, and quality controls. Fresh-Cut Fruits Veg Technol Mech Saf Control. https://doi.org/10.1016/B978-0-12-816184-5.00012-4

Lloyd JS, Milstien JB. (1999). Auto-disable syringes for immunization: issues in technology transfer. Bulletin of the World Health Organization, 77 (12): $1001-1007$. World Health Organization. https:// apps.who.int/iris/handle/10665/267952

NDTV (2021) New Delhi Television Ltd. COVID-19 vaccination centre issues guidelines for safe waste disposal of syringes. Available via DIALOG. https://swachhindia.ndtv.com/covid19-vacci nation-centre-issues-guidelines-for-safe-waste-disposal-of-syrin ges-54373/. Accessed 08 Apr 2021

Nathan JP, Vider E (2015) The package insert. US Pharmacist 40(5):810. https://www.uspharmacist.com/article/the-package-insert. Accessed 08 Apr 2021

Newland S (2011) Sustainability in vaccine packaging draft. Available via DIALOG. https://www.who.int/immunization/policy/commi ttees/Sustainability_in_Vaccine_Packaging_May11_DRAFT.pdf. Accessed 08 Apr 2021

Outlook (2021) Beware, fake COVID-19 vaccines ready to hit the market: anti-counterfeit body. https://www.outlookindia.com/website/ story/india-news-fake-covid-19-vaccines-a-big-threat-anti-count erfeit-body/366784. Accessed 08 Apr 2021

Path (2021) COVID-19 vaccine label: user evaluation. https://www. path.org/resources/covid-19-vaccine-label-user-evaluation/. Accessed 08 Apr 2021

SCHOTT (2021) Fighting COVID-19 together-SCHOTT innovation. Available via DIALOG. https://www.schott.com/innovation/en/ fighting-covid-19-together/. Accessed 19 March 2021

SGD (2018) Saint Gobain Desjonqueres. Type I molded glass vialsInternational Standards Available via DIALOG: https://www. sgd-pharma.com/sites/default/files/mediacenter-file/sgd_pharma_ type-i-molded-glass-vials-made-in-india_.pdf. Accessed 26 Apr 2021

Shanley A (2020) Can pharma quality go high tech? Pharm Technol 44(12):16-19

Sharma VK, Jinadatha C, Lichtfouse E (2020) Environmental chemistry is most relevant to study coronavirus pandemics. Environ Chem Lett 18:993-996. https://doi.org/10.1007/s10311-020-01017-6

Sharma VK, Jinadatha C, Lichtfouse E et al (2021) COVID-19 epidemiologic surveillance using wastewater. Environ Chem Lett. https://doi.org/10.1007/s10311-021-01188-w

Shastri D (2013) Vaccine storage and handling. In: Parthasarathy A (ed) Text book of pediatric infectious diseases, 1/e edn, Jaypee, India, 493-493. doi:https://doi.org/10.5005/jp/books/11900_75

Singh S, Gaikwad KK, Lee YS (2018) Phase change materials for advanced cooling packaging. Environ Chem Lett 16(3):845-859

Stevanato Group (2020) Pur Q ${ }^{\circledR}$ fused quartz vials in EZ-fill® configuration. https://www.stevanatogroup.com/en/news-events/ press-releases/pur-q-fused-quartz-vials-in-ez-fill-configuration/. Accessed 08 Apr 2021 
Sumant O (2021) Allied market research. Pharmaceutical packaging market worth $\$ 188.79$ billion by 2027 . Available via DIALOG. https://www.alliedmarketresearch.com/press-release/pharmaceut ical-packaging-market.html. Accessed 08 Apr 2021

Sun S, Han J (2021) Open defecation and squat toilets, an overlooked risk of fecal transmission of COVID-19 and other pathogens in developing communities. Environ Chem Lett 19:787-795. https:// doi.org/10.1007/s10311-020-01143-1

Thornton RG (2003) Package inserts and the standard of care. Baylor University Medical Centre Proceedings, 16 (4): (502-504)

UNICEF (2021) United nations children's fund. The right choice of a syringe. https://www.unicef.org/supply/stories/right-choice-syrin ge. Accessed 08 Apr 2021.

WHO (2021a) World Health Organization. Naming the coronavirus disease (COVID-19) and the virus that causes it. Available via DIALOG. https://www.who.int/emergencies/diseases/novelcoronavirus-2019/technical-guidance/naming-the-coronavirusdisease-(covid-2019)-and-the-virus-that-causes-it\#: :text=Offic ial\%20names\%20have\%20been\%20announced,\%2DCoV\%2D2). Accessed 07 Apr 2021

WHO (2021b) World Health Organization. COVID-19 vaccination: supply and logistics guidance. Available via DIALOG. https:// www.who.int/publications/i/item/who-2019-ncov-vaccine-deplo yment-logistics-2021-1. Accessed 15 Feb 2021

WHO (2020a) World Health Organization. Situation by country, territory and area. Available via DIALOG. https://covid19. who.int/ table. Accessed 07 Apr 2021

WHO (2020b) World health Organization. Model packaging for label for vials for Covid 19 vaccines. https://www.who.int/publicatio $\mathrm{ns} / \mathrm{m} /$ item/model-packaging-for-label-for-vials-for-covid-19-vacci nes. Accessed 26 Apr 2021

WHO (2020c) World Health Organization. Model packaging for carton for vials for Covid 19 vaccines. https://www.who.int/publicatio $\mathrm{ns} / \mathrm{m} /$ item/model-packaging-for-carton-for-vials-for-covid-19vaccines. Accessed 26 Apr 2021

WHO (2020d) World health Organization. Bar-codes, QR codes and vaccine vial monitors in the context of COVID-19 vaccines. https://www.who.int/publications/m/item/bar-codes-qr-codesand-vaccine-vial-monitors-in-the-context-of-covid-19-vaccines/. Accessed 08 Apr 2021

WHO (2020e) World health Organization. WHO launches taskforce to fight counterfeit drugs. https://www.who.int/bulletin/volumes/ 84/9/06-010906/en/. Accessed 08 Apr 2021

WHO (2009) World Health Organization. Preferred product profile for vaccines. http://www.who.int/immunization/policy/committees/ VPPAG_Generic_PPP_and_Workplan.pdf. Accessed 08 Apr 2021

WHO (2005) World Health Organization. Guideline on the international packaging and shipping of va ccines. http://whqlibdoc.who. int/hq/2005/WHO_IVB_05.23_eng.pdf. Accessed 08 Apr 2021

Wang X, Han J, Lichtfouse E (2020) Unprotected mothers and infants breastfeeding in public amenities during the COVID-19 pandemic. Environ Chem Lett 18:1447-1450. https://doi.org/10.1007/ s10311-020-01054-1

Watson KT, Barash PG (2009) The new food and drug administration drug package insert: implications for patient safety and clinical care. Anesthesia Analgesia 108(1):211-218. https://doi.org/10. 1213/ane.0b013e31818c1b27

Weikart C, Langer R. (2020) A new hybrid material for packaging COVID-19 vaccines and other biologics: Combining the best of glass and plastic. American Pharmaceutical Review. Available via DIALOG. https://www.americanpharmaceuticalreview.com/ Featured-Articles/569163-A-New-Hybrid-Material-for-Packa ging-COVID-19-Vaccines-and-Other-Biologics-Combining-theBest-ofGlass-and-Plastic/. Accessed 08 Apr 2021

West Pharma (2021) Seals—West Pharma. https://www.westpharma. com/products/vial-containment-solutions/seals. Accessed $08 \mathrm{Apr}$ 2021

Publisher's Note Springer Nature remains neutral with regard to jurisdictional claims in published maps and institutional affiliations. 